\title{
A Single Subcutaneous Administration of Buserelin Induces Ovulation in the Mare: Field Data
}

\author{
I Levy ${ }^{1}$ and G Duchamp ${ }^{2}$ \\ ${ }^{1}$ DVM, la Nouvetiere, Sonzay, France; ${ }^{2}$ Physiology of Reproduction and Behavior, INRA, Nouzilly, France
}

\section{Contents}

The aim of the present study, was to evaluate whether a single subcutaneous administration of the GnRH analogue buserelin could induce ovulation in the mare during the breeding season. Two studies were carried out under field conditions. In Experiment 1, 90 cycles of trotter mares aged 2-7 years, were assigned to a buserelin group (Bus1) or to a control group (Control), in the presence of a $\geq 35 \mathrm{~mm}$ pre-ovulatory follicle, with uterine oedema and a relaxed cervix. Ten mares were assigned to the two groups for 32 cycles in Bus1 and 52 cycles in Control, two mares received only Bus 1 for three cycles, and one mare was assigned to Control for three cycles. Mares treated with buserelin received $6 \mathrm{ml}$ of SUPREFACT ${ }^{\circledR}$ s.c. $(1.05 \mathrm{mg} / \mathrm{ml}$ buserelin acetate), and no treatment was given in Control. The ovulation rate between 24 and $48 \mathrm{~h}$ was higher $(\mathrm{p}<0.0001)$ in Bus1 $(31 / 35)$ than in Control (15/55). In Experiment 2, the condition of inducing ovulation with $6 \mathrm{ml} \mathrm{SUPREFACT}{ }^{\circledR}$ s.c. (Bus2) or 1500 ui human chorionic gonadotropin were identical to the first study. Forty-nine mares of ages 2-21 years, were used for 120 cycles, 56 cycles were assigned to Bus2, and 64 cycles were induced with 1500 IU human chorionic gonadotropin i.v. No significant difference was found in the ovulation rate on day $2(38 / 56,50 /$ $64)$, or in the fertility rate $(19 / 48,26 / 57)$. No negative effect of the treatment was observed with repeated buserelin administration in either study during the breeding season. We can conclude that a single administration of buserelin induces ovulation in the mare, under suitable conditions for veterinary practitioners.

\section{Introduction}

Greater sophistication in mare management requires more precise control of ovulation and to overcome the difficulty of predicting ovulation time it is induced. Human chorionic gonadotropin (hCG) is currently one of the most commonly administered hormones in equine reproduction management. However, it has been reported on several occasions that repeated hCG administration during a breeding season reduces the efficacy of inducing ovulation (McCue et al. 2004). It has also been demonstrated that mares with high levels of anti-hCG antibodies do not ovulate at the expected time after hCG injection (Duchamp et al. 1987). Antibody formation could be crucial in embryo transfer programmes where synchronization between donor and recipient mares is required and where induction and subsequent embryo collection of donor mare may be repeated for several successive cycles within the same breeding season. The GnRH analogue deslorelin is successfully used in the USA and in Australia but is not currently available on the market all over Europe. Buserelin, administered twice a day for 4 days, has been demonstrated to induce ovulation consistently in the mare (Barrier-Battut et al. 2001; Camillo et al. 2004), but repeated 12-hourly intravenous injections are impracti- cal in field conditions. The aim of this study was to evaluate the efficacy of a single high subcutaneous administration of buserelin acetate to induce ovulation in the mare.

Two experiments were carried out simultaneously in field conditions. In the first we compared a group treated with buserelin with a non-treated control group, and in the second we compared buserelin with hCG treatment.

\section{Materials and Methods \\ Experiment I}

In this study, 132 - to 7-year-old trotter mares, belonging to the same stud farm as recipient mares for an embryo transfer programme, were used during 90 cycles from March to November. A total of 35 cycles were assigned to the buserelin group (Bus1), and 55 cycles to the control group (Control), Ten mares were assigned to the two groups for 32 cycles in BUS1 and 52 cycles in Control, two mares received only Bus1 for three cycles, and one mare was assigned to Control for three cycles. Follicular growth and ovulation were determined by daily transrectal ultrasonography using a scanner equipped with a $5 \mathrm{MHz}$ linear probe. After prostaglandin F2 $\alpha$ (PGF2 $\alpha$ ) was injected, once a $\geq 30 \mathrm{~mm}$ preovulatory follicle was found, ultrasound examinations were performed every day until ovulation. Mares were assigned to the Bus1 or Control group when there was a $\geq 35$-mm diameter pre-ovulatory follicle, when uterine oedema was observed and the cervix was judged relaxed by transrectal palpation. The choice of group to which mares were assigned was determined by requirements of synchronization with a donor mare. In Bus1, mares received a subcutaneous injection of $6 \mathrm{ml}$ of SUPREFACT $^{\circledR}$ containing $1.05 \mathrm{mg} / \mathrm{ml}$ buserelin acetate (Aventis Pharma, Frankfurt, Germany). Mares in the control group received no treatment.

\section{Experiment II}

In this study, 49 warmblood mares, aged between 2 and 21 years, were used for 120 cycles from March to November. The mares, from a number of breeders, were kept in a stud farm for breeding management. Fifty-six cycles were assigned to the buserelin group (Bus2), and 64 cycles to hCG group (hCG). Sixteen mares were assigned, to hCG for 30 cycles, and to Bus2 for 36 cycles, 27 mares received only hCG for 34 cycles, and six mares were assigned only to Bus 2 for 20 cycles. The six mares, which were only assigned to Bus2 were those 
included in embryo transfer programme with repeated induced cycles during the breeding season. Follicular growth and ovulation were assessed daily by transrectal ultrasonography after a $\geq 30$-mm diameter pre-ovulatory follicle had been found. Mares were assigned to one of the two groups, when there was a $\geq 35$ - $\mathrm{mm}$ diameter preovulatory follicle, when uterine oedema was observed and the cervix was judged relaxed by transrectal palpation. Mares assigned to Bus2 received a subcutaneous administration of $6 \mathrm{ml} \mathrm{SUPREFACT}{ }^{\circledR}$ as previously described, and mares assigned to the hCG group received $1500 \mathrm{IU}$ hCG i.v. $\left(\mathrm{CHORULON}^{\circledR}\right.$ Intervet, Beaucouze, France). Depending on the availability of sperm, mares were inseminated either the day ovulation was induced, and the day after induction and then every day until ovulation if there was no response to treatment, or only the day after treatment when sperm was limited. A total of 41 stallions were used to inseminate mares in this study. The mares that did not become pregnant were re-assigned to the same or the other group.

\section{Statistical analysis}

Data are shown as the percentage of mares ovulating at various times, as mean \pm SEM for follicle diameters, and were analysed using a chi-squared test and Student's $t$-test.

\section{Results}

\section{Experiment I}

This experiment started on 16 March for the Control and on 31 March for Bus1 group and ended on 2 November and 13 November respectively.

The mean diameter of the pre-ovulatory follicle on the day mares were assigned to Bus1 or Control was $39 \mathrm{~mm}$ for both groups (Table 1).

The percentage of mares ovulating in the expected time limit (i.e. between 24 and $48 \mathrm{~h}$ ) was significantly higher $(\mathrm{p}<0.0001)$ in Bus1 $(89 \%)$ than in Control $(27 \%)$ (Table 2).

As shown in Fig. 1, the diameter of the pre-ovulatory follicle in the control group did not affect the interval between assignment to a group and ovulation (Fig. 1).

As shown in Table 3, there was no correlation between the month of treatment and the interval between assignment and ovulation, $\mathrm{R}^{2}=0.03$ in Bus1 and 0.004 in Control. But the interval between assignment and ovulation is longer $(\mathrm{p}<0.001)$ in Control $(2.7 \pm 0.1)$ than Bus1 $(1.9 \pm 0.05)$.

Reiteration of administration of buserelin in the same mare did not increase the percentage of ovulation

Table 1. Pre-ovulatory follicle diameter on the day of assignment to an experimental group

\begin{tabular}{lcc}
\hline Follicle size $(\mathrm{mm})$ & Buserelin & control \\
\hline Mean \pm SEM & $39 \pm 0.5$ & $39 \pm 0.9$ \\
Maximum & 45 & 48 \\
Minimum & 35 & 34 \\
\hline
\end{tabular}

Table 2. Interval between assignment to a group and ovulation

\begin{tabular}{lcr}
\hline Days & Buserelin, n (\%) & Control, n (\%) \\
\hline 1 & $4 / 35(11)$ & $6 / 55(11)$ \\
2 & $31 / 35(89)$ & $15 / 55(27)$ \\
3 & & $23 / 55(42)$ \\
4 & & $9 / 55(16)$ \\
5 & & $2 / 55(4)$ \\
\hline
\end{tabular}

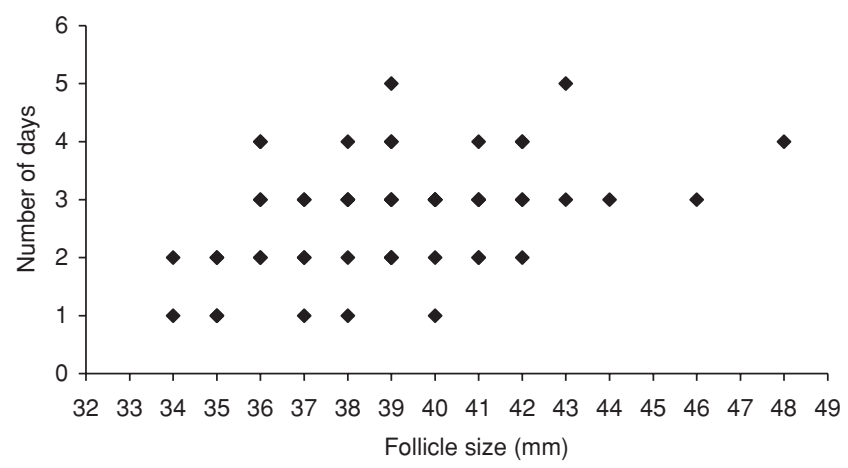

Fig. 1. Correlation between the assignment - ovulation interval and follicle size at assignment. The proportion of cycles within the lowest class of follicle size was higher in Bus2 than human chorionic gonadotropin $(\mathrm{a}>\mathrm{b} ; \mathrm{p}=0.02)$

Table 3. Mean number \pm SEM of days between assignment to groups and ovulation according to the month

\begin{tabular}{lccccr}
\hline & \multicolumn{2}{c}{ Bus1 } & & \multicolumn{2}{c}{ Control } \\
\cline { 2 - 3 } \cline { 5 - 6 } Month & Average \pm SEM & $\mathrm{n}$ & & Average \pm SEM & $\mathrm{n}$ \\
\hline March & $2.0 \pm 0.0$ & 2 & & $3.0 \pm 0.8$ & 4 \\
April & $2.0 \pm 0.0$ & 5 & & $3.0 \pm 0.0$ & 1 \\
May & $1.0 \pm 0.0$ & 1 & & $2.7 \pm 0.3$ & 11 \\
June & $1.5 \pm 0.4$ & 2 & & $2.9 \pm 0.4$ & 7 \\
July & $1.5 \pm 0.4$ & 2 & & $2.6 \pm 0.2$ & 12 \\
August & $1.8 \pm 0.2$ & 5 & & $2.5 \pm 0.3$ & 11 \\
September & $2.0 \pm 0.0$ & 9 & & $3.3 \pm 0.3$ & 3 \\
October & $2.0 \pm 0.0$ & 5 & & $2.8 \pm 0.3$ & 5 \\
November & $2.0 \pm 0.0$ & 4 & & $3.0 \pm 0.0$ & 1 \\
Total & $1.9 \pm 0.05$ & 35 & $2.7 \pm 0.1$ & 55 \\
\hline
\end{tabular}

occurring after 2 days. None of the 13 mares treated three times or more with buserelin showed delayed ovulation (Table 4).

\section{Experiment II}

Injections of hCG were administered earlier in the season than for buserelin, starting on 15 March and completed on 2 July, while Bus 2 treatment started on 17 April and ended on 8 November.

The mean $( \pm$ SEM $)$ dominant follicle size at administration of treatment in the hCG and Bus2 groups was $41 \pm 0.5$ and $40 \pm 0.5 \mathrm{~mm}$ respectively. However, when ranked by class of diameter (Fig. 2), the proportion of mares with smaller follicle size was slightly higher $(\mathrm{p}=0.02)$ with buserelin.

The percentage of mares ovulating at the expected time (i.e. on day 2) was not significantly different 
Table 4. Distribution of ovulations after repeated administration of buserelin during multiple cycles

\begin{tabular}{lcccc}
\hline & & \multicolumn{3}{c}{ Percentage of mares ovulating } \\
\cline { 3 - 5 } No. treated cycle & No. cycles & $\leq 24 \mathrm{~h}$ & $24-48 \mathrm{~h}$ & $>48 \mathrm{~h}$ \\
\hline First treated cycle & 12 & 0 & 100 & 0 \\
Second treated cycle & 10 & 30 & 70 & 0 \\
Third treated cycle & 8 & 12.5 & 87.5 & 0 \\
Fourth treated cycle4 & 4 & 0 & 100 & 0 \\
Fifth treated cycle & 1 & 0 & 100 & 0 \\
\hline
\end{tabular}

between the two groups ( $68 \%$ in Bus 2 vs $78 \%$ in hCG). Although the follicular size was slightly lower in Bus2, the proportion of mares with early ovulation (on day 1 ) was significantly higher $(\mathrm{p}=0.005)$ in Bus2 $(15 / 56)$ than hCG $(5 / 65)$. By contrast, the percentage of mares ovulating more than 2 days after treatment was significantly higher $(\mathrm{p}=0.02)$ in $\mathrm{hCG}(8 / 64)$ than in Bus2 (1/56) (Table 5).

As shown in Table 6, there was no correlation between the month of treatment and the interval between treatment and ovulation, $\mathrm{R}^{2}=0.0007$ in Bus2 and 0.035 in hCG. But the interval between treatment and ovulation is longer $(\mathrm{p}<0.001)$ in $\mathrm{hCG}(2.2 \pm 0.1)$ than Bus2 (1.7 \pm 0.1$)$.

In the hCG group, evaluation of the effect of repeated treatment during the season was not possible because only four mares received three administrations of hCG and all of them ovulated on day 2 after administration during the third cycle. These mares were 2, 5, 7 and 8 years old.

Table 7 shows the percentage of mares in different age groups ovulating on days 1,2 and $>2$. To eliminate the bias of repeated hCG administrations, only the first cycle of the breeding season was taken into account.

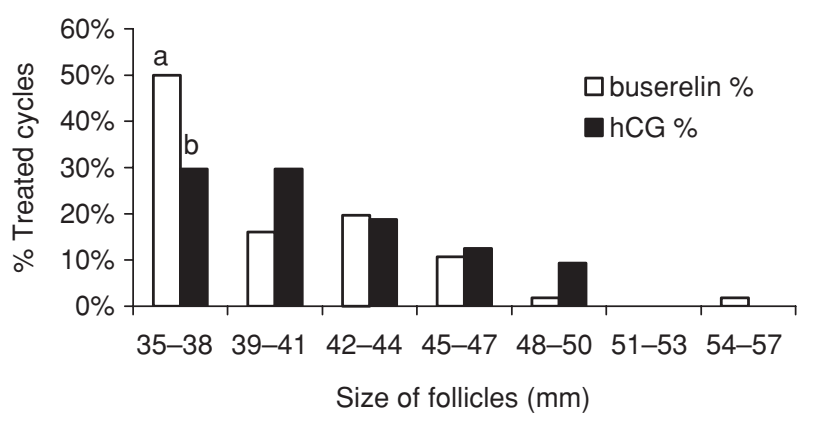

Fig. 2. Percentage of treated cycles by class of follicle size

Table 5. Distribution of ovulations after induction with buserelin or human chorionic gonadotropin

\begin{tabular}{lcr}
\hline Days & Buserelin, n (\%) & hCG, n (\%) \\
\hline 1 & $15 / 56(26.8)$ & $5 / 64(7.8)$ \\
2 & $38 / 56(67.9)$ & $50 / 64(78.1)$ \\
3 & $1 / 56(1.8)$ & $3 / 64(4.7)$ \\
4 & $0 / 56(0)$ & $3 / 64(4.7)$ \\
5 & $0 / 56(0)$ & $2 / 64(3.1)$ \\
LUF & $2 / 56(3.6)$ & $1 / 64(1.6)$ \\
\hline
\end{tabular}

LUF, luteinized unruptured follicle; hCG, human chorionic gonadotropin.
Table 6. Mean number of days between assignment to group and ovulation according to the month

\begin{tabular}{lcrlrr}
\hline & \multicolumn{2}{c}{ Buserelin } & & \multicolumn{2}{c}{ hCG } \\
\cline { 2 - 3 } \cline { 5 - 5 } Month & Average \pm SEM & $\mathrm{n}$ & & Average & $\mathrm{n}$ \\
\hline Month & & & $2.3 \pm 0.4$ & 9 \\
March & $1.6 \pm 0.2$ & 5 & $2.3 \pm 0.2$ & 11 \\
April & $1.6 \pm 0.2$ & 5 & $2.2 \pm 0.1$ & 28 \\
May & $1.9 \pm 0.1$ & 9 & $2.0 \pm 0.1$ & 14 \\
June & $1.8 \pm 0.2$ & 11 & $1.0 \pm 0.0$ & 1 \\
July & $1.6 \pm 0.2$ & 9 & & \\
August & $2.0 \pm 0.0$ & 6 & & \\
September & $1.7 \pm 0.2$ & 6 & & \\
October & $1.7 \pm 0.3$ & 3 & & \\
Total & $1.7 \pm 0.1$ & $54^{\mathrm{a}}$ & $2.2 \pm 0.1$ & \\
\hline
\end{tabular}

${ }^{a}$ Mares with LUF were not taken into account.

Table 7. Effect of age of mares on the response to human chorionic gonadotropin administration

\begin{tabular}{lcccc}
\hline & & \multicolumn{3}{c}{ Percentage of mares ovulating } \\
\cline { 3 - 5 } Age & No. mares & $\leq 24 \mathrm{~h}$ & $24-48 \mathrm{~h}$ & $>48 \mathrm{~h}$ \\
\hline$\leq 10$ years & 25 & 12.0 & 80.0 & 8 \\
$>10$ years & 17 & 11.7 & 58.8 & 23.5 \\
\hline
\end{tabular}

Although there was no significant difference, the response to hCG tended to decrease with the age of mares $(\mathrm{p}=0.13)$.

In Bus2, about a third of the mares were treated more than three times during the breeding season and no decrease in response was observed with repeated treatment during the same breeding season (Table 8).

As repeated administration of buserelin had no effect on the ovulatory response, we took into account all induced cycles during the breeding season and compared mares younger or older than 10 years of age. In Table 9 the percentage of old mares $(68 \%)$ ovulating at the expected time did not differ from young mares $(68 \%)$.

In field conditions, breeders choose the stallion, and so a variety of stallions $(n=41)$ of differing fertility were used in this study. However, no significant difference in the fertility rate was observed between the two treatments (Table 10).

Table 8. Effect on ovulation response of repeated buserelin administration during the same breeding season

\begin{tabular}{lcccc}
\hline & & \multicolumn{3}{c}{ Percentage of mares ovulating } \\
\cline { 3 - 5 } Treatment cycles & No. cycles & $\leq 24 \mathrm{~h}$ & $24-48 \mathrm{~h}$ & $>48 \mathrm{~h}$ \\
\hline $1-3$ cycles & 41 & 29.2 & 63.3 & 2.4 \\
$4-7$ cycles & 15 & 20.0 & 80.0 & \\
\hline
\end{tabular}

Table 9. Effect of age of mares on the response to buserelin

\begin{tabular}{lcccc}
\hline & & \multicolumn{3}{c}{ Percentage of mares ovulating } \\
\cline { 3 - 5 } Age & No. mares & $\leq 24 \mathrm{~h}$ & $24-48 \mathrm{~h}$ & $>48 \mathrm{~h}$ \\
\hline$\leq 10$ years & 28 & 28.6 & 67.9 & \\
$>10$ years & 28 & 25.0 & 67.8 & 3.6 \\
\hline
\end{tabular}


Table 10. Effect of the treatment on fertility rate

\begin{tabular}{lccccc}
\hline & \multicolumn{2}{c}{ Buserelin } & & \multicolumn{2}{c}{ hCG } \\
\cline { 2 - 3 } \cline { 5 - 6 } Semen & No. cycles & $\begin{array}{c}\text { Pregnancy } \\
\text { rate (\%) }\end{array}$ & & No. cycles & $\begin{array}{c}\text { Pregnancy } \\
\text { rate (\%) }\end{array}$ \\
\hline Frozen semen & 42 & 38.1 & & 47 & 42.6 \\
Fresh semen & 6 & 50.0 & & 10 & 60.0 \\
\hline Total & 48 & 39.6 & 57 & 45.6 \\
\hline
\end{tabular}

hCG, human chorionic gonadotropin.

\section{Discussion}

The first study demonstrated that a high single administration of buserelin consistently induced ovulation in mares compared with the Control group. This contradicts many previous studies that have shown that a single administration of buserelin was not effective in inducing ovulation. Different hypothesis can be put forward: (1) doses were too low to maintain a consistent LH release (only $42 \mu \mathrm{g}$ of buserelin for Vidament et al. 1992); (2) compared with s.c. administration, i.v. or i.m. reduces the duration of $\mathrm{LH}$ secretion [Ginther 1992 found that a single injection $(400 \mu \mathrm{g})$ of synthetic $\mathrm{GnRH}$ increased $\mathrm{LH}$ concentrations for $3 \mathrm{~h}$ when administered by i.v. and for $8 \mathrm{~h}$ by s.c.]; (3) other molecules than buserelin with shorter half-lives were used (Duchamp et al. 1987 unsuccessfully used $2 \mathrm{mg}$ i.m. of gonadorelin in pony mares); (4) administration of GnRH is more effective in the follicular stage than in the cycle stage Oxender and Noden 1997 did not advance ovulation significantly with $5 \mathrm{mg}$ GnRH sc given 96 h after PG $2 \alpha$ regardless of follicle size.

In our two studies, the percentage of mares ovulating within the expected time (i.e. between 24 and $48 \mathrm{~h}$ ) is similar to, or even higher than those obtained by the other teams. Barrier-Battut et al. (2001) obtained $47 \%$ of mares ovulating on day 2 with $4 \times 40 \mu \mathrm{g}$ i.v. Camillo et al. (2004), under the same conditions, found that $43 \%$ of mares ovulated within $48 \mathrm{~h}$.

In our second study, buserelin was as effective as hCG in inducing ovulation in the mare. The percentage of mares ovulating within $48 \mathrm{~h}$ was $95 \%$ and $86 \%$ in the Bus 2 and hCG groups respectively. The proportion of mares ovulating after induction with buserelin or hCG within $48 \mathrm{~h}$ and between 24 and $48 \mathrm{~h}$ is similar to those reported in the literature with hCG (Loy and Hughes 1966; Duchamp et al. 1987; Ginther 1992; Barbacini et al. 2000; McCue et al. 2004). However, the high percentage of mares ovulating within $24 \mathrm{~h}(27 \%)$ in Bus 2 is not fully understood. It does not seem related to the size of the pre-ovulatory follicle at administration, the diameter being slightly larger in the hCG group. An early ovulatory response was observed by Battut-Barrier et al. (2001) after buserelin, and was also observed by McCue et al. (2004) after hCG administration. As reported by McCue et al. (2004), the percentage of early ovulation did not increase as the breeding season progressed.

In line with Barbacini et al. (2000) and McCue et al. (2004), hCG efficacy tended to be lower in older mares. Conversely, in mares treated with buserelin we did not observe an age effect, and there was no negative effect of repeated treatment on ovulation time. This suggests that mares which failed to ovulate on day 2 with hCG had been highly exposed to this hormone in previous breeding seasons.

Although a high number of stallions with differing fertility were used, the hormones had no influence on the pregnancy rate.

OVUPLANT $^{\circledR}$ have been reported to be very effective in inducing ovulation ( $>80 \%$ ovulate within $48 \mathrm{~h}$ ) when administered to oestrual mares (Jöchle and Trigg 1994). However, it has been proved in other species and more recently in horses that GnRH treatment can downregulate the hypothalamic-pituitary axis, causing a decrease in gonadotrophin concentrations (Johnson et al. 2000). To avoid this downregulation McCue et al. (2002) recommend that the deslorelin implant be removed $48 \mathrm{~h}$ after administration. Although in our study the breeding season was long, no mares were observed with early anoestrus, including those, which were treated with buserelin for several cycles.

Further experiments are needed to evaluate subsequent gonadotrophin levels to determine more precisely, the interval between administration of buserelin and ovulation, and the interoestrus interval as sign of downregulation.

However, we can conclude that a single high subcutaneous buserelin administration consistently induces ovulation in mares, under conditions suitable for veterinary practitioners and with no decline in efficacy with repeated administrations.

\section{References}

Barbacini S, Zavaglia G, Gulden P, Marchi V, Necchi D, 2000: Retrospective study on the efficacy of hCG in an equine artificial insemination programme using frozen semen. Equine Vet Educ 2, 404-410.

Barrier-Battut E, Lepoutre N, Trocherie E, Hect S, Grand Champ Des Raux A, Nicaise JL, Verin X, Bertrand J, Fieri F, Hoier R, Renault A, Egron L, Tainturier D, Bruyas JF, 2001: Use of buserelin to induce ovulation in cyclic mares. Theriogenology 55, 1679-1695.

Camillo F, Pacini M, Panzani D, Vannozzi I, Rota AL, Aria G, 2004: Clinical use of twice daily injections of buserelin acetate to induce ovulation in the mare. Vet Res Commun 28, 169-172.

Duchamp G, Bour B, Combarnous Y, Palmer E, 1987: Alternative solutions to hCG induction of ovulation in the mare. J Reprod Fertil 35, 221-228.

Ginther OJ, 1992: Reproductive Biology of the Mare: Basic and Applied Aspects, 2nd edn. Equiservices, Cross Plains, WI.

Jöchle W, Trigg T, 1994: Contro of ovulation in the mare with ovuplant $^{\text {TM }}$, a short-term relesase implant (STI) containing the GnRH analogue: deslorelin acetate: studies from 1990 to 1994. J Equine Vet Sci 14, 632-644.

Johnson CA, Thomson DL, Kulinski KM, Guitreau AM, 2000: Prolonged interovulatory interval and hormonal changes in mares following the use of Ovuplant TM to hasten ovulation. J Equine Vet Sci 20, 331-336.

Loy RG, Hughes JP, 1966: The effect of human chorionic gonadotrophin on ovulation, length of estrus and fertility in the mare. Cornell Vet 56, 41-50.

McCue PM, Farquhar VJ, Carnevale EM, Squires EL, 2002: Removal of deslorelin (Ovuplant ${ }^{\mathbf{T M}}$ ) implant $48 \mathrm{~h}$ after 
administration results in normal interovulatory intervals in mares. Theriogenology 58, 865-870.

McCue PM, Hudson JJ, Bruemmer JE, Squires EL, 2004 Efficacy of hCG at inducing ovulation: a new look at an old issue. In: Proceedings of the 50th Annual Convention of the American Association of Equine Practitioners, 4-8 December, Denver, Colorado, USA. pp. 510-513.

Oxender WD, Noden PA, 1997: Serum luteinizing hormone, estrus, and ovulation in mares following treatment with prostaglandin $\mathrm{F} 2 \alpha$ and gonadotropin-releasing hormone. Am J Vet 38, 649-653.
Vidament M, Arnaud G, Trillaud-Geyl C, Duchamp G, Palmer E, 1992: Analogue of GnRH (buserelin) and of PGF $2 \alpha$ do not induce ovulation in mares. In: Proceedings of the 12th International Congress Animal Reproduction and Artificial Insemination, The Hague. Vol. 4, pp. 1927-1929.

Submitted: 06.08 .2006

Correspondence: Guy Duchamp, Physiology of Reproduction and Behavior, INRA, Nouzilly 37380, France. E-mail: duchamp @ tours.inra.fr 